\title{
Paixões, andamento e RitMo num Processo \\ JURÍDICO-PENAL
}

\author{
(Passions, tempo and rhytm in a criminal law process)
}

\author{
Maria Helena Cruz PISTORI*
}

\begin{abstract}
Resumo: $O$ objetivo deste trabalho é demonstrar como a intensidade passional modula um processo jurídico-penal, imprimindo-lhe sentidos. Fundamenta-se teoricamente na semiótica francesa e na retórica antiga. Apresentamos inicialmente alguns exemplos de análise de intensidade passional do processo completo, sobretudo para mostrar os meios que definimos para reconbecê-la. A seguir, visualizamos num gráfico os graus de intensidade passional de cada peça processual e relacionamos a intensidade, o andamento e o ritmo como produtores de diferentes efeitos de sentido, que passamos a comentar. Essa relação nos permite uma nova abordagem e compreensão tanto da argumentação jurídica como do fenômeno jurídico em nossa sociedade.
\end{abstract}

Palavras-chave: discurso jurídico, intensidade passional, argumentação, semiótica.

\begin{abstract}
This work intends to demonstrate how passion intensity modulates a criminal law process, contributing to the production of its different senses. It's based on French semiotics and ancient rhetoric theories. We present a few examples of passionate arguments found in the whole law process, showing the means defined to verify the passion grades involved in each of the texts. These grades are visualized in a graph which relates passion intensity, tempo and rhythm, as producers of different sense effects. Finally, we consider the contribution this approach can give to the comprehension of juridical argumentation and law phenomena in our society.
\end{abstract}

Key-words: juridical discourse, passion intensity, argumentation, semiotics.

\footnotetext{
* Pós-doutoranda em Linguística Aplicada e Estudos da Linguagem - PUC/SP; bolsista FAPESP 2009/16902-8.
} 
Este texto dialoga com duas questões presentes no senso comum. Em primeiro lugar, a percepção da lentidão processual da justiça em nossa sociedade: analisamos dados de um processo penal relativo a homicídio, que demorou quatro anos e sete meses para ter sua decisão final decretada. Em segundo, a questão da racionalidade das decisões jurídicas, na medida em que o direito se quer racional e fundamentado em códigos positivados.

Fundamentado em conceitos teóricos da semiótica tensiva, o artigo se propõe o exame da passionalidade existente tanto nas peças processuais da acusação e das defesas como nas próprias decisões, com o objetivo de aprofundar o conhecimento da argumentação na área e, ainda, apontar algumas direções para o entendimento do próprio fenômeno jurídico. Para tanto, busca relacionar a intensidade passional de um processo jurídico-penal determinado e seus tempos - cronológicos e rítmicos, verificando como as paixões podem acelerar-lhe ou não a percepção do andamento, provocando efeitos de sentido mais ou menos persuasivos.

Nosso objeto de estudo é um processo que teve grande repercussão na mídia, o caso do assassinato de um índio pataxó por cinco rapazes de Brasília. O processo foi instaurado em 23/04/1997, e a decisão condenatória final, que se manteve por não ter sido acatada apelação por redução da pena, é de 10 de novembro de 2001. Isto é, foram quatro anos e sete meses de trâmite processual, culminados na "pena definitiva de 14 anos de reclusão que serão cumpridos no regime integralmente fechado por tratarse de homicídio considerado hediondo" (fl. 2280 do Proc. 17.901/97 do Tribunal do Júri de Brasília). O artigo fundamenta-se em dados obtidos por meio da análise do processo completo, o que constituiu nossa tese de doutorado: Persuasão e eficácia discursiva no Direito: modos de ser, modos de dizer. No entanto, apresentamos aqui apenas os aspectos relevantes para a compreensão da questão selecionada: a relação entre as paixões, o andamento e o ritmo processuais.

A primeira parte do trabalho consiste dos pressupostos teóricos para análise da intensidade passional nas peças processuais; em seguida, apresentamos breves exemplos da análise que nos permitiu verificar a modulação patêmica ao longo do processo, com excertos exemplares de peças da acusação, da defesa e das decisões. Justificamos, então, a divisão do processo em quatro fases - ou movimentos, todas encerradas com uma decisão judicial, e buscamos retratar a relação andamento, ritmo e passionalidade por meio 
de um gráfico que mostra os quatro movimentos do processo: o primeiro termina com a sentença de primeira instância, que acatou a denúncia do crime, mas modificou a tipificação do delito; o segundo, acórdão do Tribunal de Justiça do Distrito Federal - decisão colegiada, manteve aquela decisão; o terceiro, acórdão do Superior Tribunal de Justiça, também uma decisão de colegiado, decide que a tipificação só pode ser definida pelo Tribunal do Júri; o quarto movimento apresenta a decisão final do Tribunal do Júri, condenando os réus por homicídio triplamente qualificado - a tese inicial do Ministério Público. Os gráficos refletem a relação tempo rítmico e tempo cronológico no todo processual e, simultaneamente, permitem relacioná-los com a intensidade passional e a aspectualização, observando o andamento - aceleração e desaceleração - da marcha procedimental. Antes de finalizar, refletimos acerca da moralização das paixões no processo e, então, nas últimas considerações, fazemos um levantamento dos sentidos que as paixões, o andamento e o ritmo lhe imprimem.

\section{Pressupostos teóricos}

O trabalho parte de pressupostos teóricos da semiótica da Escola de Paris, principalmente por textos de Algirdas J. Greimas, Jacques Fontanille, Claude Zilberberg e Denis Bertrand. Por outro lado, a análise se complementa com categorias da antiga retórica, especialmente as figuras de linguagem.

A semiótica afirma que os fenômenos passionais parecem regular a intensidade no discurso (Fontanille e Zilberberg, 2001: 297), podendo chegar mesmo a reger o processo. As paixões funcionam argumentativamente no discurso e, por vezes, imprimem-lhe novas direções. A semiótica tensiva observa ainda que a dimensão discursiva patêmica é dada pela perspectiva adotada pelo enunciador, que escolhe um ponto de vista entre os vários possíveis, e tal escolha nos revela os valores do sujeito da enunciação (Fontanille, 2003: 214). Mais do que isso, o discurso nos mostra as opções enunciativas desse sujeito e as imagens recíprocas de enunciador/enunciatário, com suas paixões e qualidades criadas discursivamente. Compreender a eficácia discursiva é apreender essas imagens (Cf. Fiorin, 2004: 69-78).

Os valores organizam cognitivamente o mundo e polarizam o próprio foco a ele dirigido. Assim, as paixões são definidas de acordo com os valores 
a que visam: valores do absoluto ou valores de universo, baseados no caráter exclusivo ou participativo, concentrado (tônico) ou extenso (átono) da valência "; "será a correlação entre a intensidade afetiva investida no objeto, por um lado, e sua quantidade ou extensão, por outro, que definirão o 'tipo axiológico’ da paixão" (Fontanille e Zilberberg, 2001: 302). Os grandes regimes axiológicos assentam na correlação inversa ou conversa de valores: as valências da intensidade modulando as energias em conflito, e as valências da quantificação, modulando as propriedades da percepção. Ainda no dizer dos mesmos autores (2001: 49): "Identificamos a exclusão-concentração, regida pela triagem, e a participação-expansão, regida pela mistura, como as duas principais direções capazes de ordenar os sistemas de valores".

A inserção do passional na práxis enunciativa mostra-nos a íntima relação entre valores e paixões, ressaltando seu aspecto intersubjetivo e social e servindo ao reconhecimento e qualificação axiológica nas diferentes culturas. Denis Bertrand (2002: 303-4) destaca a necessidade de se relativizar o caráter eminentemente subjetivo e individual das paixões, pois, do ponto de vista antropológico, poderíamos dizer que as culturas reconhecem e qualificam as paixões segundo facilitem ou entravem as trocas de valores materiais, afetivos e simbólicos no interior do grupo.

No processo jurídico-penal sobre o qual vamos nos deter, em termos da correlação tensiva, sobressaem primeiramente as variações de intensidade e extensidade dos focos e das apreensões e as predicações concessivas, mais propícias à manifestação dos efeitos passionais, responsáveis pelo afloramento textual da paixão nos vários níveis do percurso gerativo do sentido:

A concessão é uma alternativa à implicação quando a ligação entre competência e performance não é mais necessária, mas impossível ou contingente. A forma implicativa é talvez a mais estudada, mas também a menos propícia a manter a atenção de um narratário na medida em que a força da ligação de necessidade cria, numa área cultural determinada, uma espera e uma previsão muito premente (Fontanille e Zilberberg, 2001: 237).

1. "O termo valência foi adotado em semiótica para dar consistência a uma constatação muitas vezes verificada na análise dos discursos concretos: o valor dos objetos depende tanto da intensidade, da quantidade, do aspecto ou do tempo de circulação desses objetos como dos conteúdos semânticos e axiológicos que fazem deles 'objetos de valor'” (Fontanille e Zilberberg, 2001: 16). 
Destaca-se no processo, ainda, a figuratividade como provocadora de efeitos passionais, visto que ela se manifesta por meio de suas qualidades sensíveis e que a apreensão impressiva permite a manifestação direta da relação sensível com o mundo, na medida em que dá acesso a formas e valores por meio de puras qualidades e quantidades perceptivas, sem análise. Outro efeito passional importante é obtido por meio das modalizações, isto é, tudo que aponta para a subjetividade da instância do discurso (Fontanille, 2003: 17), reveladoras do julgamento avaliativo do enunciador.

Vamos considerar na análise, ainda, a questão das figuras, como metáforas, repetições, hipotipose e outras. Conforme já alertava a antiga retórica, “... os jogos de palavras, etc. são analisados pelos tratados latinos como excitantes. Num determinado sentido, toda figura é figura da paixão" (Mathieu-Castellani, 2000, p. 76). Lembremos também que, em Aristóteles, o pathos é um dos argumentos do discurso, ao lado do éthos e do lógos. Em maior ou menor intensidade, os aspectos emocionais estão presentes em todas as peças, embora, em alguma delas, realmente predomine a racionalidade cognitiva ${ }^{2}$, como, por exemplo, discussão e interpretação de lei, doutrina ou jurisprudência...

Além disso, consideramos, neste trabalho, o tempo, o ritmo e o andamento $^{3}$, também como produtores de sentido; são analisados aqui, porém, em termos do todo processual. Tipicamente impressivo, o ritmo programa, regulariza e impõe a percepção dos contrastes. O andamento, desdobrado em aceleração e desaceleração, pode ser observado enquanto produtor de efeito passional relevante. Do ponto de vista passional, as tensões sentidas pelo próprio corpo retardam, agitam ou precipitam a velocidade da percepção proprioceptiva (Fontanille, 2003: 228-9).

A marcha processual na Justiça impõe um ritmo à percepção dos sujeitos envolvidos, ritmo este que propicia uma circulação de valores mais ou menos rápida. Isso se percebe pelo número permitido de recursos, pelo prazo em que podem ser interpostos, pela maior ou menor rapidez nos julgamentos e respostas das partes adversas. A própria sequencialização e a segmentação

2. As grandes racionalidades que servem para organizar nossa experiência em discurso são as da ação - a dimensão pragmática, da paixão - dimensão passional, da cogniçãa - dimensão cognitiva. (Fontanille, 2003: 193-263).

3. Estão entre os códigos rítmicos e aspectuais de que nos fala Fontanille ao tratar dos recursos responsáveis pela manifestação textual da paixão (2002: 619). 
processuais instauram sentidos, fazendo prevalecer uma determinada predicação em detrimento de outras. Em suma, na análise adotamos o "ponto de vista da semiótica das paixões [que] é o da complexidade, isto é, das correlações entre dispositivos e dimensões provenientes de diversos níveis do percurso gerativo" (Fontanille e Zilberberg, 2001: 298).

Definidos os pressupostos, passemos à exemplificação da análise das peças, para posterior visualização da intensidade patêmica.

\section{EXCERTOS EXEMPLARES DA ANÁLISE PASSIONAL DE PEÇAS PROCESSUAIS}

Nos excertos de análise que passamos a apresentar, o primeiro aspecto de intensidade passional que destacamos são as perspectivas adotadas pela Acusação e pelas Defesas. Vejamos, neste trecho ${ }^{4}$ da Acusação, parte da narração do delito na Denúncia, primeira peça do processo:

Apurou-se, com o incluso inquérito, que os denunciados, após terem-se divertido durante toda a noite, já quase ao amanhecer, procurando dar continuidade à diversão, ao passarem pelo banco da parada de ônibus onde dormia a vítima, supondo ser ela um mendigo, deliberaram sobre a idéia de dar continuidade à diversão, fazendo do pretenso mendigo uma tocha humana.

A idéia macabra foi abraçada por todos eles, que compraram dois litros de combustível, retornaram ao mencionado local, desceram do veículo e passaram a colocar o plano em prática, tendo todos ciência de estarem contribuindo na conduta uns dos outros, com unidade de desígnio. O denunciado E. e o menor infrator despejaram o líquido inflamável sobre a vítima e os demais denunciados - MRA, ANCV e TOA - atearam fogo em seu corpo, evadindo-se a seguir (fls. 3-4).

Neste trecho, em termos de enunciação, o objeto de valor buscado é o direito, em sua extensão maior, direito de todos: a peça processual do Ministério Público apresenta um apego máximo ao direito de todos à vida. Enquanto defende este valor, mostra que os réus (actantes do enunciado) apresentam desapego ao direito - valor universal, e apego aos valores do exclusivo. No primeiro parágrafo anterior, encontramos reiteradamente este apego, na repetição do intento dos acusados - a diversão. Além disso, a metáfora - "tocha humana", exerce forte apelo passional, não apenas pelo

4. Respeitamos a forma como foram redigidos todos os trechos processuais transcritos. 
próprio paradoxo que encerra, como ainda por suas qualidades sensíveis: ela torna visível a cena, impõe uma representação.

Continuando, temos nestes dois parágrafos um exemplo da hipotipo$\mathrm{se}^{5}$, pois o texto apresenta-nos um quadro do crime como se o víssemos. A iconicidade da cena busca criar o efeito de realidade. Num crescendo, a continuidade do texto chega ao ápice da intensidade passional ao narrar a prática do delito, quando o enunciador apresenta a segmentação das diversas ações, para destacar a "unidade de desígnio" dos réus na prática desacelerada do crime (implícita a possibilidade de desistência da realização do delito a qualquer momento, entre as ações): "compraram”, "retornaram", "desceram”, "passaram”... Ao mesmo tempo em que o desapego ao direito atinge profundidade intensa, a socialidade demonstrada na ação é estrita. É uma socialidade de grupo, deste grupo. Este modo de discretização - a correlação inversa: quanto mais intenso o apego ao valor - diversão, menos extensa a sociabilidade -, cristaliza as contradições (cultura vs. não cultura, oposição privativa), convertendo-as em contrariedades (natureza vs. cultura, oposição qualitativa).

Por outro lado, destaquemos agora um exemplo com aspectos passionais em texto da defesa. Ao mesmo tempo em que o Ministério Público busca suscitar argumentativamente a indignação do enunciatário, a argumentação inicial das defesas procura suscitar a compaixão - paixões opostas, segundo Aristóteles - do enunciatário em relação aos réus: “a tragédia que se abateu sobre a vítima, não está muito além da que explodiu sobre a cabeça dos ora acusados" (fl. 561). Mais adiante, no entanto, para rebater a forma como o Ministério Público narrou o delito, uma das defesas utiliza passionalmente o ressentimento:

Depois de insistir na tese da diversão "até as três horas da madrugada”, diz a Promotoria, cheia de ódio e ressentimento, que os cinco rapazes "trocaram de carros numa surpreendente seqüência de vezes" carregando as tintas da cizânia sobre um dos acusados: "Só MAX, naquela noite fatídica, usou diversos carros de luxo, alguns importados, muito acima dos padrões dos carros brasileiros comuns".

5. "A hipotitose consiste em que, numa narrativa ou, mais frequentemente ainda, numa descrição, o narrador seleciona uma parte somente das informações correspondentes ao conjunto do tema tratado, abordando tão somente as observações mais sensíveis e fortes, chocantes, sem dar a visão geral do que se trata, sem indicar mesmo o tema global do discurso. Os aspectos selecionados são apresentandos sob expressões falsas ou de pura aparência, relacionando-as sempre a um tipo de registro cinematográfico do desenvolvimento ou da manifestação exterior do objeto" (Molinié, 1992: 168. Tradução própria). 
Percebe-se, nesse ponto, um laivo de inveja, uma ponta de inconformismo da acusadora oficial, como se fosse pecado alguém, depois de vários anos de trabalho sério e anônimo, possuir mais de um carro importado ou não. Parece não ser, evidentemente, da alçada da "Fiscal da Lei" imiscuir-se em área não afeta à sua competência legal (fl. 758).

A emoção exemplificada neste trecho, misto de ressentimento e indignação contra o Ministério Público, é clara não apenas no próprio léxico e nas modalizações - "cheia de ódio e ressentimento", mas também no alertar a respeito da emocionalidade expressa na descrição dos réus: "Percebe-se (...) um laivo de inveja, uma ponta de inconformismo da acusadora oficial, como se fosse pecado alguém (...) possuir mais de um carro importado ou não” (itálicos nossos), em oposição à descrição do mendigo “desamparado". Ao discutir a quantidade de álcool derramada sobre a vítima, esta defesa também reage com apreciativos axiológicos enfáticos: "Não se faz uma análise fria e desapaixonada da ação criminosa em pauta, mas um estudo fantasioso, fúnebre e tendencioso dos lamentáveis acontecimentos” (fl. 761. Itálicos nossos).

Consideramos ainda importante um breve exemplo da presença da passionalidade também nas decisões. É emoção garimpada pela análise, mas demonstra uma perspectiva mais próxima da defesa, apego ao direito "fragmentado" dos indivíduos, isto é, aplicado em extensão menor, expresso em leis específicas, mas também garantido pela Constituição. Vamos retirá-los das duas sentenças mais importantes do processo: a primeira, emitida por enunciador singular ${ }^{6}$ e a última, decisão do Tribunal popular, mas também elaborada por um enunciador-juiz singular, responsável por dosar a pena.

A primeira sentença acata a tese defensória de que não houve a intenção de matar; portanto, o crime deve ser tipificado como "lesões corporais seguidas de morte”. Alguns aspectos da argumentação passional da sentença são: (i) o léxico utilizado, através de modalizadores de intensidade como, por exemplo, em "está totalmente afastado pela prova dos autos, que demonstrou à saciedade que os acusados pretendiam fazer uma brincadeira selvagem..."

6. As decisões processuais são elaboradas por um juiz singular - se de primeiro grau, ou por uma turma (de três a cinco juízes), quando de segundo ou terceiro grau. Neste processo, a última decisão coube ao Tribunal do Júri, quer dizer, é coletiva, pois cabe ao Conselho de Sentença a decisão acerca da culpabilidade do réu; ao juiz togado, no entanto, cabe elaborar a motivação do que foi decidido e dosar a pena. 
(Itálicos nossos); (ii) a correlação inversa: "Por mais ignóbil que tenha sido a conduta irresponsável dos acusados, não queriam eles, nem eventualmente, a morte de Galdino Jesus dos Santos" (fl. 590. Itálicos nossos): quanto mais ignóbil a conduta, menos ignóbil o intento apresentado, a correlação inversa, reveladora de passionalidade.

$\mathrm{Na}$ decisão final, verificamos, entre outros aspectos passionais, o modo como o enunciador interpreta o delito em julgamento, parecendo, primeiramente, acatar tese do Ministério Público: "Agiram com culpabilidade, demonstrando desprezo para com um semelhante, independente de tratar-se de índio ou mendigo - ambos seres humanos”. Há solidariedade e identificação em relação à vítima na escolha lexical: "semelhante", "seres humanos"; mas é função do enunciatário o preenchimento dos implícitos ${ }^{7}$ - ele deve saber que os réus se desculparam da ação praticada, afirmando não saberem ser a vítima um índio. No entanto, mais adiante, quando trata da "conduta social" dos agentes, o enunciador assume a perspectiva das defesas, afirmando que ela "é boa e a personalidade, embora selvagem o ato praticado, não se mostra deturpada por ora”. Mais uma vez é a concessão, baseada na correlação inversa - passional, o que chama a atenção na fundamentação da "boa" conduta social dos condenados: quanto mais selvagem o ato, menos deturpada a personalidade. É a confrontação entre programa e contraprograma cujos objetos de valor estão em oposição: o apego aos valores do exclusivo ou do universo, que se expressa nesta "concessão", definindo-se os valores do privilégio como mais intensos que o outro (cf. Zilberberg, 2002: 343). O argumento se basearia na presunção de que "a qualidade de um ato manifesta a da pessoa que o praticou" e é uma presunção muito encontrada no campo jurídico.

7. Em termos de "implícitos" da sentença, vale a referência ao estudo de Bertrand (2000: 29-45), sobre a proximidade entre os conceitos de textualização (da semiótica) e entimema (da antiga retórica), justamente por ser comum a comparação entre a sentença judicial e o silogismo lógico. Na realidade, ela mais se aproximaria do entimema, estrutura elíptica, cujos espaços de sentido significam pela falta, e é preenchido pelo enunciatário, instância de enunciação sensibilizada, interpretativa e passionalmente. Esses espaços convocam e referencializam um saber supostamente adquirido, um lugar comum, uma evidência, instalando o caráter verossímil ou provável, mas também relativo, contestável e discutível da conclusão. Assim como a textualização, que sofre as constrições da linearidade no discurso verbal e apresenta a manifestação enunciativa do sentido, mas também oculta parte dela. Isso dá ao enunciador uma margem estratégica na qual se move, escolhendo o que mostra e o que oculta, hierarquiza, suspende e expande, dirigindo a leitura. 
Perelman e Olbrechts-Tyteca (1996: 75-83) afirmam que a argumentação voltada para o auditório universal baseia-se em fatos, verdades e presunções. No entanto, dizem eles, a adesão às presunções não é máxima, ela serve, sobretudo, para reforçar a adesão às teses propostas. Nesta sentença, a "presunção" não se sustenta, já que prevalece a orientação argumentativa do enunciado não introduzido por embora; dessa forma, a frase chega a parecer paradoxal, pois proposição ou opinião contrária ao senso comum, com aparente falta de nexo lógico entre o ato cometido e a presunção. A passionalidade demonstra a compaixão em relação aos acusados.

\section{O TEMPO, O RITMO E O ANDAMENTO}

Após a breve exemplificação de recursos passionais nas peças processuais, tratemos da questão proposta: sua relação com os tempos cronológicos e rítmicos. Como já afirmamos, analisamos o tempo, o ritmo e o andamento, também produtores de sentido, em termos do todo processual. As quatro decisões acatam, sob novo foco enunciativo, argumentação produzida num determinado intervalo de tempo. A decisão incorpora tudo que a precede, constituindo-se uma supratextualidade, em termos de síntese - de informações, declarações, descrições, indícios, relatórios, pareceres, etc. - e individualização. Assim, ao se proceder à análise de uma sentença, pratica-se a análise do movimento dos textos que influenciaram a decisão e do próprio movimento criativo do texto decisório (Bittar, 2001: 272).

Ao demarcar o processo em quatro movimentos, destacamos a nova orientação discursiva a ser levada em consideração após cada uma das decisões. A aspectualização colabora para que se perceba a ritmização no conteúdo processual: cada decisão se destaca por seu aspecto terminativo e aponta para a incoatividade do movimento seguinte. $\mathrm{O}$ andamento processual, contudo, apresenta-se mais tenso ou relaxado no interior de cada movimento, em que a segmentação, ordenada segundo o procedimento legal, ocorre por meio da sequência das peças. O ritmo expressa-se, então, também na alternância de peças átonas e tônicas passionalmente, que obedecem à regularidade sequencial do próprio processo legal.

As peças que integram os gráficos constam do relatório dos atos procedimentais que ocorreram até o julgamento final do delito e é parte integrante da Sentença final; foram todas analisadas em termos de intensidade 
passional. Houve outras peças não registradas, constitutivas, sobretudo, de um discurso de tipo "burocrático" (cf. Bittar, 2001, p.167-182), que serve preferencialmente à ordenação, impulso e orientação dos ritos institucionais. Em termos de eficácia persuasiva para a decisão final, foram textos menos relevantes; exerceram, porém, o fazer fazer necessário ao andamento processual, e ainda proporcionaram ritmo ao processo, acelerando-o ou desacelerando-o.

\section{Visualizando A INTENSIDAde PASSIONAL}

As datas das peças, marcadoras do tempo cronológico, permitem que se deduzam, por catálise, a possibilidade de ocorrência dos discursos burocráticos - particularmente os muitos despachos e protocolos que permeiam o processo, tornando mais lento seu ritmo. Cumprem uma função de afrouxamento passional e racionalização das práticas jurídicas. Utilizamos a notação e terminologia musical para aproximarmo-nos do sentido da relação andamento/ritmo/intensidade passional. Dessa forma, assim denominamos os quatro movimentos processuais: 1. Grave. Allegro maestoso; 2. Allegro appassionato; 3. Andante con fuoco e 4. Largo assai. Adagio lamentoso.

A modulação dos discursos ao longo de cada movimento aponta-nos a tonicidade das peças processuais, momentos em que identificamos um conjunto maior de recursos passionais que influenciam a direção do julgamento - por isso, notas mais altas (de 1 a 7) de intensidade passional. São momentos em que é a paixão a regente do processo: tonicidade mais forte, tempo mais vivo, intensidade mais ruidosa; a extensão, porém, varia conforme a axiologia em vigor, apego aos valores do universo - mais intensidade no direito à vida, direto de todos, ou do exclusivo - intensidade maior no direito de poucos, neste caso, dos réus. Repetem-se, nos quatro movimentos, o esquema retórico canônico (Bordron e Fontanille, 2000: 3-15): uma confrontação de posições, assunção de cada uma delas conforme perspectivas da acusação ou da defesa, e resolução final, com a posição enunciativa dominante.

Cada peça dialoga, simultaneamente, com o todo e com a parte. Verifiquemos que, no primeiro movimento, por exemplo, houve um Habeas Corpus (09/05/97) impetrado pelo réu MRA, que só dialoga, à primeira vista, com a decisão (coletiva, de turma de Tribunal) a seu respeito. A 
primeira consequência disso é óbvia, o réu permanece preso até a decisão final, pois sua prisão é mantida ao longo de todo processo. No entanto, mais adiante constatamos no processo que o ACóRDÃo que fecha o segundo movimento será julgado exatamente pela mesma turma que negou o HC àquele réu, pois ela se considerou legalmente competente (preventa) para tal. E o mesmo enunciador-desembargador apaixonado da primeira vez (26/06/1997) expressa-se da mesma forma passional no ACóRDÃo de 05/03/1998.

Levando a analogia musical um pouco adiante a fim de compreender melhor a marcha procedimental, independentemente do procedimento legal, podemos empregar aqui os conteúdos que Eero Tarasti (Tarasti, 2002: 545-562; Fontanille e Zilberberg, 2001: 315-6) deu às modalidades musicais: nos dois primeiros movimentos - Grave. Allegro ${ }^{8}$ maestoso e Allegro appasionato, o processo é impulsionado energeticamente pela paixão: é o querer atenuar o crime e o querer atenuar a pena, por parte da defesa, que se sobrepõem ao dever jurídico do Estado. $\mathrm{O}$ andamento é mais acelerado. No terceiro e quarto movimentos - Andante con fuoco e Largo assai. Adagio lamentoso -, muito mais técnicos e desacelerados, o poder expressar-se com "virtuosidade e tecnicidade" destaca o saber jurídico, "o estoque de informações disponíveis e conhecidas". Os diferentes efeitos veridictórios buscados nos vários discursos - o crer verdadeiro, cumprem, enfim, seu papel de manipulação entre enunciador e enunciatário na SENTENÇA final: as diversas transformações ao longo do processo mostram-nos o sentido apreendido, a resolução conflitual patrocinada pelo Estado.

No primeiro movimento (Fig. 1), com duração cronológica de menos de 4 meses (139 dias), a dimensão patêmica da DENÚNCIA, embora de alta intensidade, refere-se ao delito. As defesas prévias de ANCV, TOA e ECO, formulaicas, apresentam baixa tonicidade. No entanto, a defesa do quarto réu - MRA, antes mesmo de responder àquela DENÚNCIA - o que só pôde fazer no momento processual legalmente estipulado, apresenta: (i) o pedido de Habeas Corpus; (ii) uma defesa prévia que se distingue das outras, por já apresentar arrazoado em favor do acusado; (iii) um requerimento para que o réu não seja fotografado pela imprensa; (iv) o pedido de oitiva

8. Embora Allegro seja um andamento musical leve e ligeiro, a aceleração ou desaceleração é sempre relativa; e relativa não apenas ao andamento dos outros movimentos, mas também ao que é observado na maior parte das vezes nos processos, conforme indicaremos adiante. 
de outra testemunha, além das oito já relacionadas (a dona da pensão em que se hospedara a vítima). Embora nem todas essas peças apareçam em nosso gráfico, pois não estão presentes no relatório final, propiciam um retardamento ao seguimento processual... Estão aí como que a constituir um pano de fundo, na tentativa de postergar as decisões... E intensificando os valores do exclusivo.

Primeiro movimento

Grave. Allegro maestoso

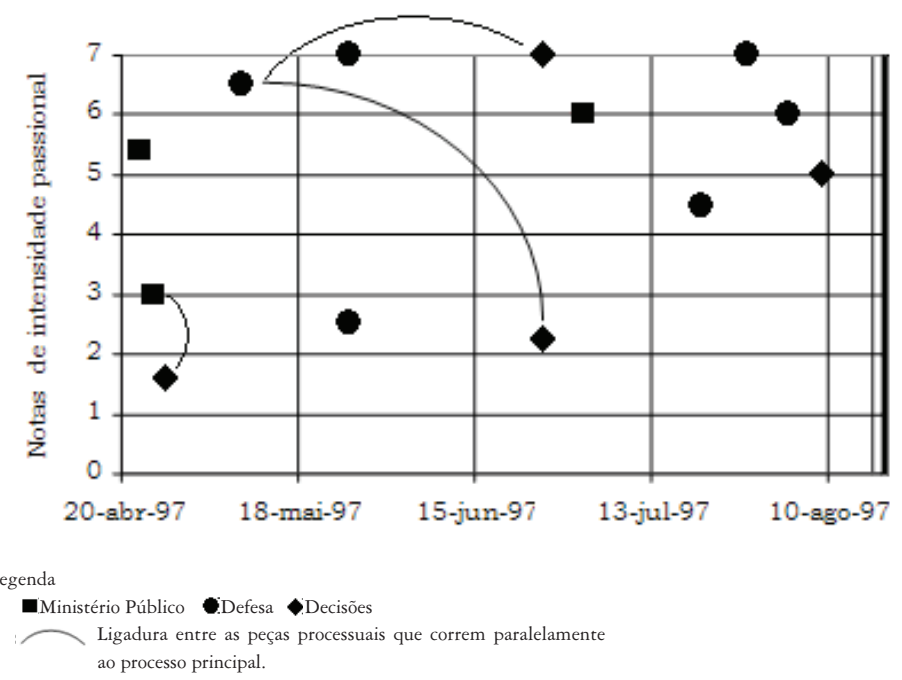

Figura 1.

Essa mesma possibilidade de retardamento ocorre no segundo movimento (com duração cronológica de quase 8 meses - 236 dias. Fig. 2), após a desclassificação do crime: agora, porém, é o Ministério Público que recorre, seguido pela Assistência de Acusação, que entra ainda com embargos de declaração. Além disso, externamente ocorre um HABEAS CORPUS procurando liberar a FUNAI, cujo sentido é, na realidade, reformar a SENTENÇA de desclassificação. Em resposta a eles, há o recurso, não citado no relatório final, para que seja publicada a SENTENÇA de desclassificação, a fim de que seja conhecida pela comunidade jurídica, novamente da defesa de MRA. 
Segundo movimento

Allegro appassionato

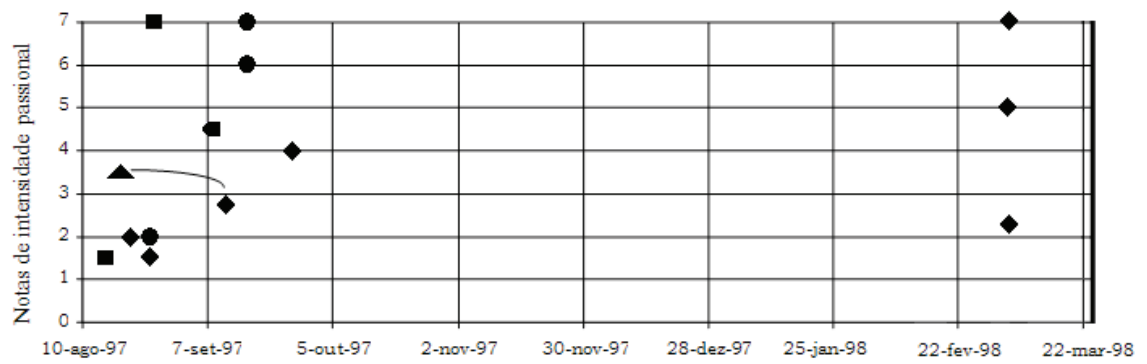

Legenda

- Ministério Público Defesa Decisões $\mathbf{\Delta}$ HC em favor da Funai

Ligadura entre as peças processuais que correm paralelamente

ao processo principal.

Figura 2 .

O terceiro movimento - Andante con fuoco (com duração de quase 11 meses - 334 dias. Fig. 3) apresenta intervenções simétricas: recursos especial e extraordinário, interpostos pelo Ministério Público, suscitam Contrarrazões ao Superior Tribunal de Justiça e ao Supremo Tribunal Federal das defesas, que redundam no acórdão que decidiu pelo julgamento dos réus pelo Tribunal do Júri.

Terceiro movimento

Andante con fouco

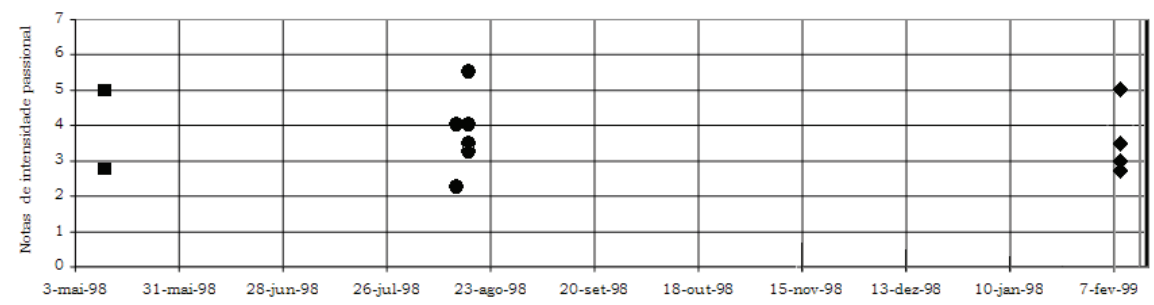

Legenda

-Ministério Público

Defesa Decisões

Figura 3. 
No quarto movimento - Largo assai (duração de aproximadamente 33 meses - 961 dias. Fig. 4), são os embargos de declaração ao recurso especial, seguidos dos embargos de divergência, impetrados pelas defesas, que serão rejeitados liminarmente pelo Superior Tribunal de Justiça. Chega-se, então, finalmente ao ápice processual, o libelo-crime acusatório. De intensidade passional apenas ligeiramente acima da média, é peça que traz em si toda a história dos praticamente quatro anos processuais. É da enunciação - que lhe permite a ocorrência, que lhe advém a intensidade passional, e não da tecnicidade com que é elaborada. A resolução ocorre na SENTENÇA final, no Adagio lamentoso que condena os réus e dosa a pena por meio de uma "reprimenda" sancionadora.

O discurso burocrático é responsável pelos longos períodos de silêncio, tanto no terceiro quanto, sobretudo, no quarto movimento: no terceiro, recursos de maio e agosto de 1998 são julgados apenas em fevereiro de 1999; no quarto, os primeiros embargos são de 03 de março de 1999, mas julgados apenas em 23 de março de 2001, e a sentença final será prolatada em 10 de novembro desse mesmo ano, compreendendo um total de 1669 dias. O processo, porém, só se encerrou em 23 de maio de 2002, quando foi negado provimento à apelação da Defesa de MRA, totalizando 1862 dias

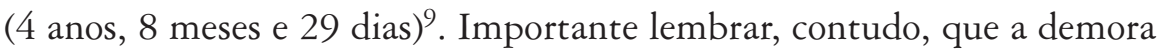
no julgamento também é devida ao acúmulo processual: há vários estudos que apontam para a relação insuficiente, no país, entre as ações ajuizadas e o número de juízes por habitante ${ }^{10}$.

9. Casos célebres de homicídio não são garantia de julgamento rápido. A condenação do ex-estudante de medicina Mateus da Costa Meira a 120 anos de reclusão por triplo homicídio levou 1.674 dias. O ex-ator Guilherme de Pádua, que confessou em 1992 ter matado a atriz Daniella Perez com 18 tesouradas, teve de esperar 1.486 dias (ou quatro anos e 25 dias) entre a sua prisão e a sentença. No caso do motoboy Francisco de Assis Pereira, conhecido como "maníaco do parque", foram 1.166 dias entre a prisão e o julgamento do primeiro dos seus sete homicídios. Nesses exemplos podemos perceber a diferença de tempo em termos de privilégios sociais, que permitiram defesas mais competentes e empenhadas nos dois primeiros casos e, consequentemente, julgamentos mais lentos. 10. Desde 2003, o Conselho Nacional de Justiça (CNJ) é o órgão responsável pela pesquisa desses dados, publicados em Justiça em Números. 
Quarto movimento

Largo assai. Adagio lamentoso
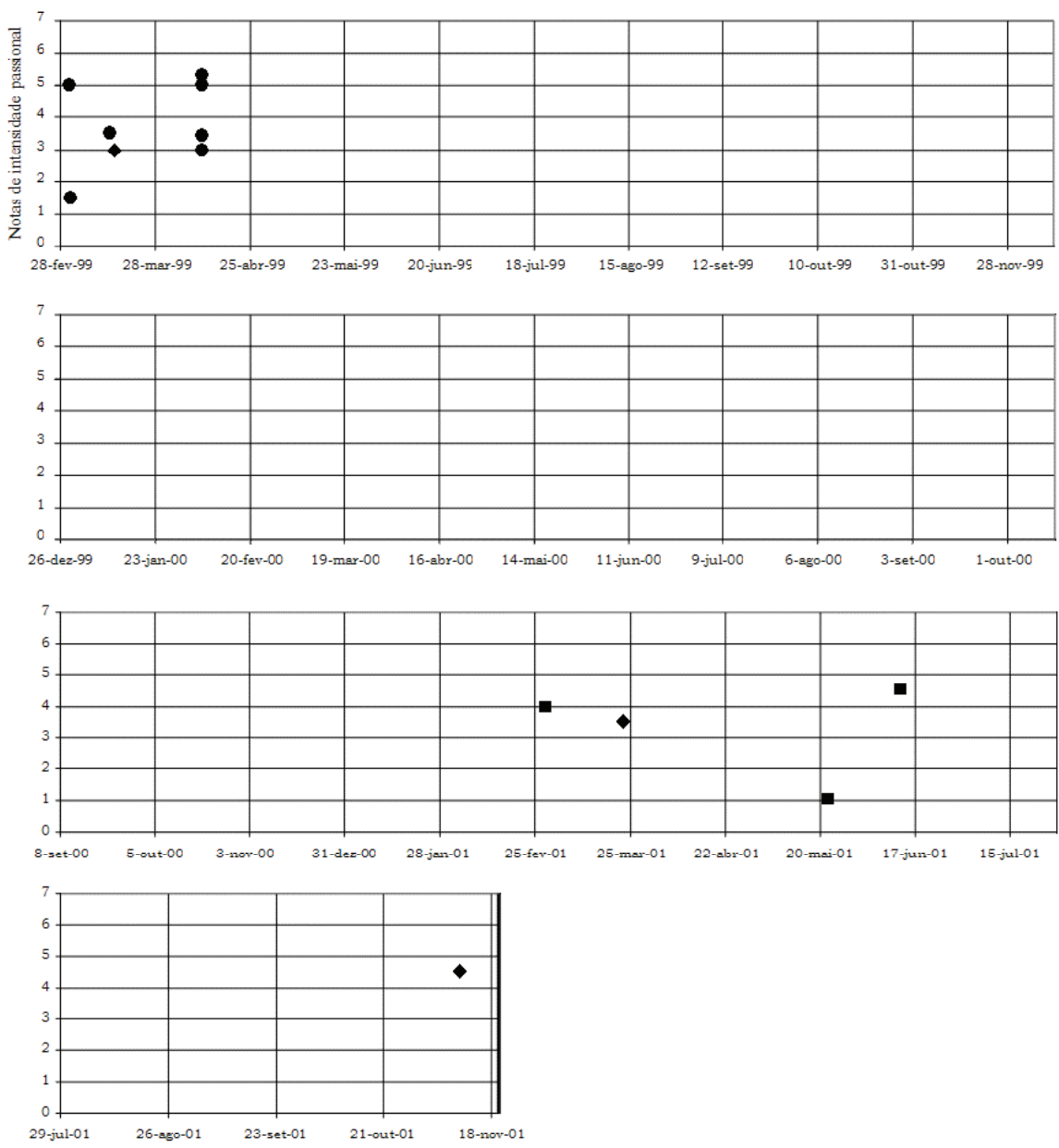

Legenda

- Ministério Público

- Defesa Decisões

Figura 4. 


\section{A moralização das Paixões no Processo}

A relação entre as paixões presentes no processo e os valores a ela ligados aponta para uma ética que indica o justo e o adequado diante da situação concreta do crime. Esta questão já estava presente na Retórica aristotélica. Por exemplo, quando o filósofo apresenta a paixão da cólera, mostra igualmente de que maneira sua manifestação pode ser justa: "Admitamos ser a cólera uma tendência acompanhada de pena que nos incita a tomar vingança manifesta por um desdém manifesto, e injustificável, de que tenhamos sido vítimas, nós, ou algum dos nossos" (II, 1378b 30. Itálicos nossos).

A democracia, ou mais especificamente, o Estado Democrático de Direito em que vivemos, não prevê as paixões, mas garante os direitos que constituem objetos de valor no processo judicial. A própria Constituição Federal dá suporte e referenda esta ética, conforme observamos no art. $5 .^{\circ}$, que aborda os direitos em confronto: direito à vida, à liberdade, à igualdade e à ampla defesa:

Todos são iguais perante a lei, sem distinção de qualquer natureza, garantindo-se aos brasileiros e aos estrangeiros residentes no País a inviolabilidade do direito à vida, à liberdade, à igualdade, à segurança e à propriedade, nos termos seguintes:

(...)

LV - aos litigantes, em processo judicial ou administrativo, e aos acusados em geral são assegurados o contraditório e ampla defesa, com os meios e recursos a ela inerentes.

De forma ampla, poderíamos afirmar que esses direitos se inserem na axiologia constante da taxionomia cultural brasileira, uma grade cultural que revela modos de sentir que levam a modos de agir. Presente na acusação e na defesa de formas diferentes, na medida em que o objeto de valor a que se apegam é apreendido com maior ou menor extensão - direito de todos à vida ou direito dos réus à defesa, a compaixão pode se mostrar mais ou menos socialmente justa. Assim, em relação a ela, a axiologia cultural brasileira assenta-se na correlação conversa: quanto mais poder/querer estar junto com o direito (de todos), mais justa a compaixão - compaixão política, todos iguais perante a lei. Já a indignação, dirigindo-se a posições tomadas pelo antissujeito - a defesa (e antes, aos próprios agentes do crime), baseia-se na correlação inversa: quanto menos o antissujeito quer e pode estar junto do direito de todos, mais justa a indignação. 
Os deveres cívicos expressam-se no princípio da legalidade: "Ninguém será obrigado a fazer ou deixar de fazer alguma coisa senão em virtude de lei" (CF., art. 5. ${ }^{\circ}$, inc. II). Daí decorrer, como nos mostra o processo e já afirmavam Greimas e Fontanille (1993: 83), que "os comportamentos [sejam] socialmente normatizados, codificados como papéis temáticos na competência dos sujeitos, permanecendo no âmbito de um contrato coletivo e de uma competência moral ordinária". Por isso, as paixões expressas pela Acusação e pelas Defesas são moralmente aceitas quando condizentes com os deveres cívicos e com os direitos fundamentais, expressos na Constituição Federal, particularmente em seus art. $1 .^{\circ}$ e art. $3 .^{\circ}$, nos excertos abaixo:

Art. $1^{\circ}$ A República Federativa do Brasil, formada pela união indissolúvel dos Estados e Municípios e do Distrito Federal, constitui-se em Estado Democrático de Direito e tem como fundamentos: (...)

II - a cidadania;

III - a dignidade da pessoa humana; (...)

Art. 3. ${ }^{\circ}$ : Constituem objetivos fundamentais da República Federativa do Brasil: I - construir uma sociedade livre, justa e solidária.

\section{CONSIDERAÇÕES FINAIS}

Neste processo, a concentração dos valores do exclusivo - maior intensidade na tese das defesas, prevaleceu nos $1 .^{\circ}$ e $2 .^{\circ}$ movimentos. A correlação tensiva impôs o enfraquecimento do termo correlato. No entanto, esses são justamente os movimentos em que a aceleração processual é maior, se comparada com o que acontece a seguir. As possibilidades processuais de recurso são muitas, a ponto de, no relatório final, tomarmos conhecimento de que o juiz solicitou das defesas que renunciassem a qualquer outro recurso (fl. 2203).

Percebemos ainda que a alta intensidade passional dos primeiro e segundo movimentos não mantém a persuasão do enunciatário, pois a tipificação do delito é modificada no terceiro movimento. É justamente neste último, e também no quarto, que observamos o declínio intensional da argumentação patêmica: embora continue presente, atinge graus menores. Isso parece nos indicar que, ao menos na área jurídico-penal, há um nível aceito e adequado de emocionalidade para se obter a persuasão: é um nível 
de média intensidade, conforme nos mostram os gráficos. Os argumentos do lógos, que expressam a prudência - phrónesis do orador, assim como a virtude ética por excelência - a areté (cf. Eggs, 1999, p. 31-59), capacidade de se mostrar discursivamente sincero, honesto, equitativo e corajoso, revelam-se mais persuasivos e eficazes no discurso jurídico.

No caso analisado, a vítima é claramente um excluído da sociedade. É o confronto entre exclusão e privilégio um dos fatores que dão maior notoriedade ao caso, levando a sociedade a ficar atenta à atuação da justiça. O Ministério Público, em nome da sociedade, insiste na obtenção da condenação, irresignado com a possibilidade de julgamento por um juiz singular; teme o privilégio na aplicação da justiça aos "privilegiados". Com base na análise empreendida na tese, apenas minimamente exemplificada neste trabalho, podemos afirmar que a acusação esgota as possibilidades processuais para obtenção do resultado que considera justo; por outro lado, a defesa atua também de forma bastante competente. O saber jurídico e retórico de ambas é bem exercido. As tentativas de postergar a decisão com recursos extras, a fim de arrefecer os ânimos excitados pela proximidade temporal com o crime, são estendidas ao máximo pelas defesas; a acusação, porém, responde a todas.

Talvez seja esta lentidão processual ${ }^{11}$, admitida não apenas pela legislação como também pela própria infra-estrutura judicial deficitária, que nos permita perceber nosso sistema judiciário como uma estrutura que tende para a clara e lenta semiótica da triagem. E essa percepção é tão nítida que, no processo, a todo momento, observamos a interferência da sociedade, ora por meio do Ministério Público, ora por meio de menções a ela feitas -

11. Levantamento inédito realizado pelo Seade (Fundação Sistema Estadual de Análise de Dados), que analisou mais de 7 milhões de processos no Estado de São Paulo, entre 1991 e 1998, verificou que são gastos, em média, 1.431 dias ( 3 anos, 11 meses e 6 dias) para mandar o autor de um homicídio para a prisão. Em Campinas (SP), entre 1988 e 1992, o prazo até o julgamento é de 1.716 dias (quatro anos, oito meses e 16 dias) quando o réu está solto. Com o réu na prisão, o tempo entre o boletim de ocorrência e a sentença cai para 623 dias (um ano, oito meses e 18 dias). < http:// clipping.planejamento.gov.br/Noticias.asp?NOTCod=128190> em 06/12/2007.

Outra pesquisa, realizada na Região Metropolitana de Florianópolis, por integrantes do Laboratório de Estudos das Violências (Levis), ligado ao Departamento de Antropologia da UFSC, revelou que entre o crime e o julgamento dos acusados há um tempo médio de espera de dois anos. Segundo essa mesma pesquisa, a questão do tempo de processamento, assim como o fluxo de justiça, são temas praticamente inexplorados no Brasil. < http://209.85.165.104/search?q= cache:ZGEuVKuncqQJ:www. agecom.ufsc.br/index.php\%3Fsecao\%3Darq\%26id\%3D5207+tempo +tramita\%C3\%A7\%C3\% $\mathrm{A} 3 \mathrm{o}+$ justi\%C3\%A7a+homic\%C3\%ADdio\&hl $=\mathrm{pt}-\mathrm{BR} \& \mathrm{ct}=\mathrm{clnk} \& \mathrm{~cd}=1>\mathrm{em}$ 06/12/2007. 
mídia, opinião pública, políticos: estão todos atentos para que os excluídos participem, tenham seu direito à vida respeitado; em outras palavras, que os réus sejam condenados. O lugar que a exclusão concede à participação deve ser bem ocupado na busca da justiça em relação ao crime.

Recebido em março de 2010

Aprovado em abril de 2010

E-mail: mhcpist@uol.com.br

\section{REFERÊNCIAS BIBLIOGRÁFICAS}

ArISTÓteles. 2006. Retórica. $3^{\mathrm{a}}$. ed. Trad. e introdução de Manuel Alexandre Júnior. Lisboa: Imprensa Nacional / Casa da Moeda.

Bertrand, Denis. 2000. Enthymème et textualisation. In: Langages. Paris: Larousse, Mars, 137.

. 2002. Sémiotique littéraire. In: Henault, A. Questions de sémiotique. Paris: PUF.

BitTAR, Eduardo. 2001. Linguagem jurídica. São Paulo: Saraiva.

Bordron, Jean-François e Fontanille, Jacques. 2000. Présentation. Langages. Sémiotique du discours et tensions rhétoriques. Paris: Larousse, Mars, 137.

EGGS, Ekkehard. 1999. Ethos aristotélicien, conviction et pragmatique moderne. In: Amossy, Ruth (org.). Images de soi dans le discours. La construction de l'ethos. Lausanne \& Paris: Delachaux et Niestlé S.A.

Fiorin, José Luiz. 2004. O pathos do enunciatário. Alfa - Revista de Lingüística. São Paulo, v. 48, n. 2: 69-78.

Fontanille, Jacques. 2002. Sémiotique des passions. In Hénault, A. Questions de sémiotique. Paris: PUF.

. Sémiotique du discours. $2^{\text {éme }}$. ed. Limoges: PULIM, 2003.

Fontanille, Jacques e Zilberberg, Claude. 2001. Tensão e significação. São Paulo/ Discurso Editorial: Humanitas/FFLCH/USP.

Greimas, Algirdas Julien e Fontanille, Jacques. 1991. Semiótica das paixões. São Paulo: Ática.

Mathieu-Castellani, Gisèle. 2000. La rhétorique des passions. Paris: PUF.

Molinie, Georges. [1992]. Dictionnaire de rhétorique. Paris: Librairie Générale Française. 
Perelman, Chaïm \& Olbrechts-Tyteca, Lucie. 1996. Tratado da Argumentação. A Nova Retórica. São Paulo: Martins Fontes.

Pistori, Maria Helena Cruz. 2008. Persuasão e eficácia discursiva no

Direito: modos de ser, modos de dizer. Tese de doutorado em Letras. Universidade de São Paulo.

TARASTI, Eero. 2002. Un éclairage sémiotique sur l'histoire de la musicologie.

In: Hénault, Anne (dir.). Questions de sémiotique. Paris: PUF.

Tatit, Luiz. 1997. Musicando a Semiótica. Ensaios. São Paulo: AnnaBlume.

Zilberberg, Claude. 2002. Seuils, limites, valeurs. In: Hénault, Anne (dir.). Questions de sémiotique. Paris: PUF. 